\title{
Analysis of Non-Formal Education Leadership
}

\author{
Widodo, S. Mundzir, Ach. Fatchan, Hardika \\ Non Formal Education Departement \\ Malang State University \\ Malang, Indonesia \\ widodo48@ymail.com
}

\begin{abstract}
Research UNESCO (2008) states that the NFE (Non Formal Education) program in Indonesia has the characteristic "on-off", dependent on government funding, leadership, and community support. The success of NFE programs at CLC influenced by the type of leader and leadership. Activity education program will run properly and effectively if they have effective leadership. So, the study focused on the analysis of models of leadership in NFE program, accordance with the characteristics of Indonesia. This study with a qualitative approach to the type of case studies with the informant; director, secretary, treasurer, CLC tutors. Data were collected through dept interviews, participant observation, and study documentation relating to focus. The results showed that the characteristics of the leader NFE, include; trustworthy, creative and innovative, communicative, commitment to service, risk-taking attitudes, and religious. Leadership strategies in NFE based on community needs, is; to maintain trust, reduce dependence on government funding, program innovation, open management, internal correction, intensive coordination, flexibility in management, relationship collegial or friendship, build partnerships, continuous improvement. Constructivist charismatic leadership has high enthusiasm, have good selfconfidence, and can provide the best solution. Five characteristics of effective leadership, is; 1) to have a vision, 2) can realize good vision, 3) are willing to take risks in realizing the vision, 4) are concerned with the environment and the needs of society, and 5) have a personality that is 'different', 6) a build from the zero. So, the leadership model NFE is charismatic constructivist leadership that emphasizes the importance of contextual factors and equality of all those involved in NFE, and build from the ground. This theory is often called constructivist charismatic leadership.
\end{abstract}

Keywords-leadership, non-formal education (NFE), constructivist, charismatic

\section{INTRODUCTION}

Non-formal Education (NFE) is organized outside school education system that serves as a replacement, supplement and complement in order to support lifelong learning. Non-formal education can be a replacement, meaning that non-formal education to be "aligned" with formal education and not subordinate of formal education [1]. To get the 'alignment' of the required management of Non-Formal Education were both referring to the standard that has been set, so it can be recognized in parallel with formal education both from the process and learning outcomes [2]. For that, the NFE must be managed by professionals.
CLC (Community Learning Center) is a unit of NFE which organizes a variety of learning activities in accordance with the needs of society 'from', 'by' and 'for' the people. In the framework of efforts to improve the knowledge, skills, attitudes, hobbies and talents citizens who starts from the significance and usefulness of programs for residents to learn to explore and exploit the potential of human resources and natural resources in the environment. Technical instructions CLC Ditjen PAUDNI describes the guiding principle used 'from', 'by' and 'for' the people. UNESCO research result, that the CLC held in Indonesia, the government is responsible for providing the funding requirements and to ensure its implementation monitoring and evaluation of programs [3]. Even surprising results of the study stated that the CLC in Indonesia is highly dependent on the allocation of funds from the government as much as half the total operational needs. Unesco study in the CLC Country Report from Asia (2008) states that the leader and leadership is a dominant factor in the CLC [3]. By Zolfaghari (2009) call the local leadership affecting NFE [4]. Atmaja (2012) and Chang and Yoo (2012) concluded that this aspect of leadership affects the independence of NFE programs in the CLC [5] - [6].

The community activity program will not run properly and effectively if the absence of effective local leader, local leaders have a major role in providing resources such as financial and material support. NFE program's success depends on the attitude of the leaders to the changes in society, if the leader has a positive attitude towards change, courage, motivation and willingness to initiate some action for the benefit of the entire society, then the change will occur. Likewise, with the leadership model developed and manage an aspect that can support the success of NFE. It is needed to do research related to leadership model in the non-formal education field to support the development of NFE practices in achieving autonomy.

This study focuses on non-formal education leadership style as a social reality that are processing delivers NFE to be autonomous. The focus of research is the behavior of leaders in managing the NFE program until the condition becomes independent CLC institutions.

Management and leadership are the elements that relate to and affect the success of the program. These two elements cannot be separated roles and functions, so that the existence of necessity inherent in organizing non-formal education program. Etymologically distinguished between the terms of 
management, leadership, and leadership. Management activity involves coordinating and overseeing the work activities of others so that reviews their activities are completed efficiently and effectively [7]. Management is an effort to move all the potential of the CLC in achieving the goals and targets that have been set.

Management is the process of planning, organizing, leading and controlling the efforts of organizing members and of using all other organizational resources to achieve stated organizational goals" [8]. Management is the ability and skills to perform an activity, either together or with others in achieving organizational goals [9]. As stated by Frederik W. Taylor that the management principles that must be considered, is; the need to develop knowledge for each task (guidelines motion, implementation of working standards and eligible work condition), the selection of the right employees in accordance with the requirements of employment, the need for training and stimulation, the need to do research and experiment [10].

Crosby also provides a stage in achieving quality of education, namely; management commitment, quality improvement team, quality measurement, the cost of quality, the building of quality awareness, corrective action, zero defect planning, supervisor training, the holding of a zero-defect day, goal setting, error-cause removal, recognition, the establishment of quality councils, do it over again [11]. By Joseph M. Juran in quality management, namely; intense focus on the customer, concern for continual improvement, process focused, improvement in the quality of everything the organization does, accurate measurement, empowerment of employees [7]- [11]. Based on the principles by some experts can be implemented and developed in non-formal education programs, namely; oriented to the needs and problems of the community, have a shared commitment in continuous improvement, give serious attention to the learning process or the empowerment of communities, to make sure every part of the program is in good condition, their quality standards/quality of non-formal education programs, establish a good team work.

Process management is the implementation of management functions consists of 4 (four), i.e.: planning, organizing, leading, and controlling. Applicatively that the NFE program management function consists of planning, organizing, motivating, controlling, evaluating and developing. Some expert opinions on management functions can be summarized that the NFE program management function consists of five main functions: planning, organizing, actuating, controlling, and evaluation [7]- [ 8]- [9].

Planning involves defining the organization's goals, establishing strategies for achieving reviews those goals, and developing plans to integrate and coordinate work activities [7]. Organizing is the act of building an effective relationship between the performance of the people in order to achieve common goals [12]. Activities are included in the organization include activities; dividing the components needed to achieve the goals in the group, share responsibility for a manager to organize the division of labor groups, establish the authority in each group or organizational unit [12]. Actuating is also called 'motion of action' activities carried out by managers to initiate and continue the activities set out in planning and organizing so that objectives are achieved [12]. The essence of the actuating function in NFE program; affects a person to be willing to follow the program NFE, to soften the resistance power to individuals or groups in the institution and the community, make everyone likes to do a good job, nurture and foster commitment and dedication in implementing the NFE program, and instill and nurture a sense of responsibility on NFE program implementation. Controlling is process of monitoring, comparing, and correcting work performance [7]. The function controlling program NFE effective include; must be linked with the objectives and criteria used in the program NFE, establish standards that can be achieved and measured, adjusted to character and needs of the community, suitable with needs, is controlled by a flexible surveillance system, refers to the supervision of improving actions, refer to the troubleshooting procedures. Stufflebeam is more focused on the function of the evaluation result from the decision making that is educational evaluation is the process of delineating, obtaining and providing useful information for judging decision alternatives [9]. Stages in the evaluation are (a) to collect information, (b) manage it, (c) analysis, (d) describe and (e) represent it in a report [8].

Leading is effort to create an atmosphere of support to do the work in order to achieve individual and organizational goals both inside and outside of someone. Thus, it forms the motivation and conditions that are convenient for everyone working doing all the work. Wadsworth said it needed a harmonious combination of inner leadership to achieve these changes, the logical intelligence, emotional intelligence, skill in making a good relationship, and good communication skills [13].

Leadership is the ability to influence the behavior of a person or group to achieve a goal [8]-[ 9]. Management is a specialized skill and ability to perform an activity, either with others or through others to achieve goals. A leader is someone who can influence other and who has managerial authority [7]. Leadership is a process of leading a group and influencing that group to achieve its goals. Managers should be leaders because leading is one of the four management function. Leadership implemented in NFE program has differences with general education. Leadership in relation to the achievement of objectives CLC (Community Learning Center) has a big role, because it can affect the other and who have managerial authority while leadership is the process of leading the group and influence the group to achieve its goals [7]-[13]. NFE build continuous leadership to autonomous in performing the administration of NFE program gradually. The stages of the process of leadership actualization, namely (a) the process of intra-individual, which is a process that occurs self-awareness in decision making, motivation, and awareness explained the leaders behavior, (b) dyadic processes, namely the process of reciprocity influence between the leader and others as followers, (c) a group process that is naturally or conditioning can occur in individuals to groups, (d) the process of institution / organization which can provide a big influence [14]. Applicatively leadership in NFE, Describes the characteristics of leadership, including; physics characteristics, intelligence 
and ability, personality characteristic, task related characteristics, social characteristics [9].

NFE leadership is an individual perspective and the object of study. Leadership is a process from a person to emphasize its strong influence on others to guide, create a structure, facilitating activities and relationships within a group or organization [14]. While the term leader is a subject, person or group of people whose influence in achieving the objectives of the institution or organization. Various terms for a leader is a manager, manager or administrator.

Leadership is a process of an influencing group to achieve goals [7]. Shows some leadership model that consists of three kinds, namely (a) R \& D, (b) problem-solving, (c) social interaction. [13]. Muhammad research found there were four models of leadership, namely; Brotherhood leadership, collaborative leadership, consultative leadership, and support leadership [15].

Some research results can be concluded about effective leadership style is divided into several kinds as follows; (a) autocratic, (b) democratic, (c) laissez-faire, (d) consideration, (e) initiating structure, (f) high-high leader, (g) the managerial grid. Path-Goal Model in leadership also called Path-Goal Theory, which has identified four leadership behaviors as follows (a) directive leader, (b) supportive leader, (c) participative leader, (d) achievement oriented leader [7]. Generally, it can be started that leadership style may increase organizational learning and pave the way for achieving the goals of an organization [16].

\section{METHODS}

In this study using this case studies type in qualitative research methods to explain a phenomenon of leadership in managing NFE in the CLC [17]. Choosing the case study is based on the phenomenon of NFE leadership which able to provide education for the community as well, achievement of local, regional, and national levels, thus providing a significant impact on society.

Data collected from the informant; CLC chairman, secretary, treasurer, and tutors through the technique of indepth interviews, observation participative, and documentation activities. Further analysis is done through several steps of qualitative research data analysis previously performed data collection, namely; 1) data reduction 2) display of data, 3) the conclusion. Analysis using four techniques perform data validity as follows; a) credibility, b) dependability, c) transferability, d) confirmability). Cycles can be seen in the following picture [17].

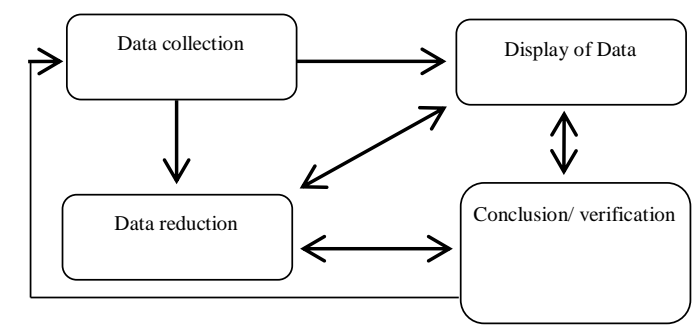

Fig. 1. Interactive Model Cycle Data Analysis

\section{RESULTS AND DISCUSSION}

\section{A. Results}

Non-Formal Education (NFE) leadership is part of an effort to make 'construction'. Itis needed efforts in creating awareness, directing and guiding people towards the empowerment. Construction leadership of non-formal education is intended to guide the community for the autonomy of NFE programs.

NFE leadership appears, based on encouragement (drive) and purpose (motive) action performed by someone who cares about the problems of society. Efforts to integrate ideas and opinion that a person has with other parties in order to bring an institution. The institute raised by those who have same the understanding and idea, so the motivated and driven one build NFE activity for the community. As stated by Guk Dien (CLC leader), as follows.

"The government is very concerned with the school by various aid, what about children with problems that can't be school? for example children of the poor, lodged a criminal matter, gay and social problems, children who have to work to help their parents, 'their disability'. Continues responsibility, is it? I make this underlying NFE institutions. Because we see that in the community that there are only two problems, namely poor and stupid, they are poor because of stupid and stupid because they are poor. We anticipate that by learning to overcome poverty with life skills education, then for his stupidity with literacy learning "(Guk Dien).

Therefore, create NFE institutions to help solve community problems. The attitude in pioneering stages of NFE institutions, including: (a) the risk-taking attitudes with the various problems encountered, (b) committed to serve the community with the "religious service" intention in the society of 'nahdliyin' people. (c) patient and wise in dealing people with different backgrounds knowledge and needs and (d) follow the rules with by 'consistent' care in having licensing activities of the institution, so institution can organize NFE program concerned to the needs of society.

Select and assign appropriate NFE program and the community needs based on the potential of each region. NFE program established then be published to the general public. The public will choose according to their interests and needs by joining study given, such as; courses and training, Qur'an study gathering, educational equality, literacy education, and community empowerment. Thus, service for community through non-formal education can be held.

As for leadership in non-formal education are directly in contact with the complexity of the society through several stages. Stage in non-formal education leadership includes; (a) risk-taking attitudes (risk takers) with the various problems encountered. The attitude of the leader Non Formal Education always deal directly with the society has various problems needed courage, especially 'culture' of rural communities is still 'old-fashioned' difficult to change. Thus, society as the majority will follow the attitude of the leader. (b) Committed to serving the community with the "religious service" intention in 
'nahdliyin' community. The value of ' religious service ' to be possessed by a leader. This could also be interpreted sincerity in providing non-formal education for the community is the attitude of a leader must have. Commitment to provide this service makes a leader is always respected and has its own charisma. (c) Be patient and wise in dealing with people with different backgrounds knowledge and needs. NFE leader attitude that always face the community problem. Required patient and wise in dealing and providing services to the community. (d) Following the rules to maintain the continuity and development of NFE program.

Aspects of the NFE leadership in order to strengthen the implementation of the program include; (a) a sense of belonging on each of the human resources involved in NFE. A sense of belonging is a must in NFE leadership, where the sense of NFE program is implemented to 'belong' together. There is a moral responsibility of the community to participate and to succeed the non-formal education activities. (b) the public trust that consists of community 'older generation', adolescents and children, especially the community leaders (key people). Public trust is an aspect that involves 'accountability' and 'credibility' himself a leader. Accountability themselves leaders with regard to the duties and responsibilities given, and the leader's credibility is related to the ability of a leader in implementing the NFE leadership. (c) Respect everyone in society, especially community leaders. NFE based on principled by and for the community. NFE sustainability of programs that provide services for the learning needs of the community will be better if 'accepted' by the public. Essentially a mutual appreciation of the community leaders from community member. (d) Establish NFE program management aspects i.e.: build a strong team, raise funds for the running of programs, establish institutional partnerships, socialize and publish NFE program. (e) Creating autonomy programs funded from the public trust. People who have the 'power' is really should be 'trusted' his mandate. So, that the public trust given to a leader who can organize in the Non-Formal Education program.

\section{B. Discusion}

Leadership NFE is a natural process of how to get the trust management and administration. Interaction is the relationship of the individual to another individual. Interaction between individuals to one another in order to share information and each influences the other. So, from each influences the process will crystallize leaning on the strength of the effect. Influential forces can be seen in the social reality in which individuals interact and gain confidence. Based on some of the analysis can be encapsulated in the following proposition: "The leadership of NFE is the formulation of a natural interaction in managing and directing the NFE program to achieve the goal". While leaders of non-formal education are an individual or group of individuals who have the ability and gain confidence through natural interactions in the community to carry out NFE programs effectively and efficiently.

Leader in NFE is born from the public, in other terms for their 'personage' someone in the community. Accordingly, also the NFE leadership is a natural interaction formula in managing and directing the NFE program to achieve the vision which has been formulated together.

Vision of a leader's direction or destination where the institution going. Leading with a futuristic vision of a rational and decomposes in the mission and objectives of the institution CLC. Should be simple and idealistic vision, a picture of the desired future, not an elaborate plan that has quantitative targets and detailed action steps [14]. Vision calls for the values, hopes, and ideals of members based organizations and other stakeholders to support. Goal pragmatic vision far exceeded expectations and the expectations to be realized, the necessary trust and the future can be achieved that the base makes the current conditions. Vision must focus to guide decisions and actions, opening opportunities for initiative and creativity in the strategies used to achieve it.

NFE effective leadership with vision approach. Where is the vision of a 'building' the future we should create a reference, everyone involved in NFE program? The vision that has been understood everyone involved in NFE programs at CLC is the main capital in conducting activities in making them. Summarizes of some expert opinion and research results, that the formulation of the vision in leadership (a) involve the stakeholders, (b) identify strategic objectives, (c) identify strategic elements, (d) connecting the vision with competition, (e) evaluating, (f) continuously assess and refine the vision [14].

Visionary leader is the vision of a dynamic driving force in implementing programs of NFE through the stages that have been determined until the realization of 'building' vision believed to be together. Vision developed in CLC leadership is realized by gradually each year an evaluation and assessment of the achievement of the vision. Achieve independence in the management CLC was launched in 2018 which periodically will be achieved through the activities of NFE programs. Based on the analyzes that have been raised can be formulated that a leader in constructing his leadership through a clear vision and measurable based on the ideals of the institution. Without the vision, explicit and measurable by idealism institutions, the leadership will not work effectively in the running NFE program. The realization of the non-formal education leadership is visionary, the leader is always oriented investments in organizing the NFE program to maintain the continuity and independence of the program.

Leadership developed in managing NFE programs are acceptable to all parties, of all the institutions to the board on all citizens to learn. The leader is very familiar to the board and residents to learn, even in the division tasked not too pushy. The agency can finish the job done properly. Relations with the leaders of other administrators and collegial ties structural hierarchy 'vague'. So, one can evoke trust, loyalty and motivation of the people involved in program action in achieving its objectives. By Burn is called transformational leadership [14].

Bass, the leader of change and motivate the followers; (a) provides awareness to subordinate the importance of results, (b) concerned with the affairs of the institution rather than personal interests, (c) prioritize the needs of subordinates [14]. NFE leadership resulting from the analysis of the data collected 
led to the fact that leaders encourage the emergence of a strong motivation and dedication in carrying out its duties and authorities. The creation of a subordinate who has the motivation and dedication good value. The process involves the internalization of self-affect workers with motivating and delivery of attractive vision. Will possibly generate attribution of charismatic leadership. Making leaders have 'charisma' to 'lure' of subordinates to carry out its duties and authorities in achieving the objectives of the institution that became independent CLC. Type action constructivist charismatic leader NFE has six (6) characteristics, as follows:

a. Having a clear vision, which became an independent institution in organizing the NFE program in 2018. Gradually make efforts to eliminate dependence on government funds. A clear vision and measurable understood by the board CLC into capital strength to move to achieve it.

b. Develop a concrete strategy to realize the vision, namely; (a) build trust, (b) establish a partnership with the relevant institutions NFE program, (c) create a business unit in various forms, (d) professionals in the management of NFE achieve the vision of becoming an independent CLC.

c. Brave any risk in realizing self CLC. Not easy to realize the vision, but as a leader who has great ambition will always strive for the realization of the vision although many risks that must be faced. Leaders change risks is a challenge that must be completed and passed. Risks associated with program funding NFE, cherished time, ideas and energy that should be devoted to care, as well as 'social risk' to be borne to raise CLC.

d. Care for the environment, the needs of society, and society's problems given solutions through NFE program. NFE charismatic leader who cares about the environment that can be used as a land of devotion. So, the presence of CLC through NFE program can impact the environment, can provide a solution to the problem, and have an attitude of 'serving' the learning needs of the community.

e. Personality leaders 'different' and unique that always emphasizes on simplicity. NFE leader in serving board leadership and the people they lead. Leadership NFE is a 'character' of society with the necessary skills. 'Personage' leaders in the leadership of NFE is a persona that is entrenched in the community. So, that people naturally make leaders without coercion, because it can provide the service and lived in simplicity in the simple village communities.

f. Growing leadership is built from the bottom through the stages that require a lot of time and sacrifice.

Various studies put forward by the experts on leadership viewed from various aspects cited, include; early theories, contingency theories, contemporary theories of leadership. Likewise do the classification leadership viewed from several perspectives and leadership to explain the classification [7].

Leadership has a different meaning to each other, because of the leadership seen from a different perspective. As has been studied by IOWA University is seen from the perspective of authority and communication. The results show there are three (3) types namely autocratic leadership style, democratic style, and laissez-fair style [12].

Classify NFE leadership in various aspects of the approach, as follows.

a. The approach is based on the characteristics (characteristic approach) include; charismatic leadership and transformational leadership. Charismatic leadership have five (5) characteristics, as follows; (a) have a clear vision, (b) be able to realize the vision of a well, (c) willing to take risks in realizing the vision, (d) care or care about the environment and the needs of society, and (e) has a personality that is 'different'. Transformative leadership that is capable of providing inspiration and stimulation for employees to work well. Transformational leadership creates the spirit of work and performance for the institution. NFE leadership closer to the characteristics of charismatic leadership that emphasizes developing a vision and risk-taking in realizing the vision that has been set. This can be seen in the characteristics of charismatic leadership that can be implemented on NFE program, as follows; vision is to be built is an institution NFE independent in 2018, has stages in realizing the vision as a form of readiness in the process, take a risk by continuing to strive to create new things that are creative and innovative, cares about the success of the community that the program -Program empowering the people and leaders of NFE have 'style' that is different from the formal educational leadership, a more relaxed yet full of creativity.

b. An approach based on human behavior (behavior approach), include; authoritarian leadership, democratic leadership, and free leadership.

c. Situational approach, that this approach emphasizes the importance of contextual factors such as the nature of work performed by the unit leader, external environmental properties and characteristics of his followers. This theory is often called contingency theory.

Leadership NFE conducted in accordance with the characteristics and needs of the learning program. Servant leadership learning needs, can help solve the problem, and can create a welfare society will be easy to follow. Key leadership NFE direct contact with the public is a sincere attitude of service to the learning needs, have a degree of 'sacrifice', and high spirit to educate the community.

The characteristics NFE leader in the research that the following, include; (a) have the will to lead not just to manage the program NFE, (b) maintain the moral high ground in the community, (c) the commitment and teamwork, (d) enthusiasm for implementing the program NFE, (e) look to the future with optimism into CLC standalone year 2018, (f) to take risks prudently in the development program, $(\mathrm{g})$ honest financial management, (h) goes on tirelessly, (i) understand the program NFE well, (j) instill religious values and social, (k) oriented to the needs of the community, (l) firmly in taking decisions, (m) sets standards and objectives, (n) makes suggestions and criticism challenges and opportunities develop, (o) confident, 
(p) responsibility, (q) do not be afraid to pair with and compared, (r) have a winning mentality, (s) curiously, (t) always learn different (innovative).

NFE good leadership Strategies based on the community needs are as follows; (a) keep trust maintenance with community involvement, (b) reduced dependence on government funding but by developing program business unit (KBU) to generate funds to finance the program, (c) perform NFE innovation program in order to get the public trust, (d) open management programs, especially in financial matters, give opportunity to all of the board or leadership team to audit the financial condition of the institution, (e) internal-correction controlling to remain institution programs, (f) often make coordination committee to update new information and share the problems faced in the process of implementing the program, ensuring activities run well, (g) flexible management to avoid things that are formal and static, (h) develop boards 'collegial' relationship or friendship, so will be created familiarity and friendly condition, (i) establish partnerships with other institutions, (j) continuous improvement on NFE program implemented.

Leadership analysis perspective of the NFE discussed from several approaches. The approach in the leadership analysis of NFE proposed as follows: the approach based on the characteristics, emphasis on personal leadership attributes [12]. The basic theory states that some people are leaders with some characteristics that not owned by others. In this group, among others, are divided into the charismatic leadership, and transformational leadership. The leader characteristics and leadership is obvious in behavior that emerged in the process of leadership.

The public or employees leader are selected based on the participation characteristics based on the 'admiration' on the individual leader called charismatic leadership. Constructivist charismatic leadership has high enthusiasm, has good selfconfidence, and carries out activities of his leadership by providing the best solution [7].

Constructivist charismatic leadership has six (6) characteristics, as follows; (a) have a clear vision, (b) be able to realize the vision, (c) willing to take risks in realizing the vision, (d) care about the environment and the needs of society, and (e) has a 'different' personality, (f) a build from the zero. While someone chosen based process that shows the role of encouragement, motivation of employees in carrying out the activities called transformational leadership. The transformative leader is able to inspire and stimulate employees to work well. Transformational leadership creates the work spirit and performance for the institution.

NFE leadership model is more to be constructivist charismatic. The leaders figure has a considerable influence on the leadership. Constructivist charismatic leadership that can be implemented on NFE program, as follows; vision that will be built i.e.: an autonomous NFE institution, has stages in realizing the vision as a form of readiness in the process, take a risk by strive continously to create new creative and innovative things, cares about the community success i.e.: the empowering program for society and leaders of NFE has a 'style' that is different from the formal educational leadership, a more relaxed but full of creativity and a building from the zero.

\section{CONCLUSION}

NFE leadership model is more to be constructivist charismatic. The leaders figure has a considerable influence on the leadership. Constructivist charismatic leadership that can be implemented on NFE program, as follows; vision that will be built i.e.: an autonomous NFE institution, has stages in realizing the vision as a form of readiness in the process, take a risk by strive continously to create new creative and innovative things, cares about the community success i.e.: the empowering program for society and leaders of NFE has a 'style' that is different from the formal educational leadership, a more relaxed but full of creativity and a building from the zero.

However, when used situational approach, the NFE leadership tends contingency. Leadership which conditions can change the style according to the conditions in where the leadership performed.

\section{REFERENCESS}

[1] Etllng Arlen,"What Is NonformalEducation ?"Journal of Agricultural Education.Accesed, 15 October 2014.1993.

[2] Gimbuta, "Nonformal education; a logical analysis of the term". Journal Plus Education (online) Vol. VII, No2 (pp. 266-286), 2011.

[3] UNESCO, "Community Learning Centres (CLC) Country Reports from Asia”. UNESCO Bangkok, 2008.

[4] Zolfaghari, Akbar. "The Factors Contributing to the Success of Community Learning Centers Program in Rural Community Literacy Development in the Islamic Republic of Iran: Case Studies of Two Rural Communities. Journal Asian Culture and History (Vo.1, No. 2), pg. 103108, 2009.

[5] Atmadja, dkk. "Kajian Pusat Kegiatan Belajar Masyarakat (PKBM) Mandiri Berbasis Kewirausahaan wilayah Jawa Timur dan Indonesia Timur. Laporan tidak diterbitkan, 2012.

[6] Chang \& Yoo, "Popular education for people's empowerment in the Community Learning Center (CLC) project in Bangladesh". Journal Korean Educational Development Institute (KEDI): pp. 363-381, 2012.

[7] Stephen Robbins\& Mary Coulter, "Management, 11th Edition". USA: Prentice Hall, 2012.

[8] T. Hani Handoko, "Manajemen; edisi 2", Yogyakarta: BPFE UGM, 2009.

[9] Sudjana,"Manajemen Program Pendidikan; untuk NFE dan Pengembangan Sumber Daya Manusia. Bandung : Falah Production, 2004.

[10] Nanang Fattah, "ManajemenPendidikan", Bandung: Alfabeta, 2001.

[11] Edward Sallis,"Total Quality Management, thirt edition". British: Taylor \& Francis e-Library, 2005.

[12] George R Terry, "Giude to Management, edisi terjemah "Prinsip-Prinsip Manajemen” oleh J. Smith. Jakarta: Bumi Aksara, 2012.

[13] Walter Wadsworth, "Global Bussines Library; Leadership", (terjemah oleh At's Line). Yogyakarta: Tugu Publisher, 2004.

[14] Gary, Yulk, "Leadership in Organization; five edition", (alih Bahasa: Budi Supriyanto), Jakarta: PT. Indeks, 2005.

[15] Muhammad J, Ali, "Educational Leadership a New Tread that Society Needs", Elsevier-Procedia-Journal Social and Behavioral Sciences 210 (2015) pg. 28-34.

[16] Roya Golmoradi \& Farzad Sattari A. "The effect of Social Capital and Leadership Style on Organizational Learning". Elsevier-ProcediaJournal Social and Behavioral Sciences 230 (2016) pg. 372-378.

[17] Miles \& Huberman. "Analisis data Kualitatif; Buku Sumber Tentang Metode-metode Baru. Jakarta: UI-Press, 2009. 